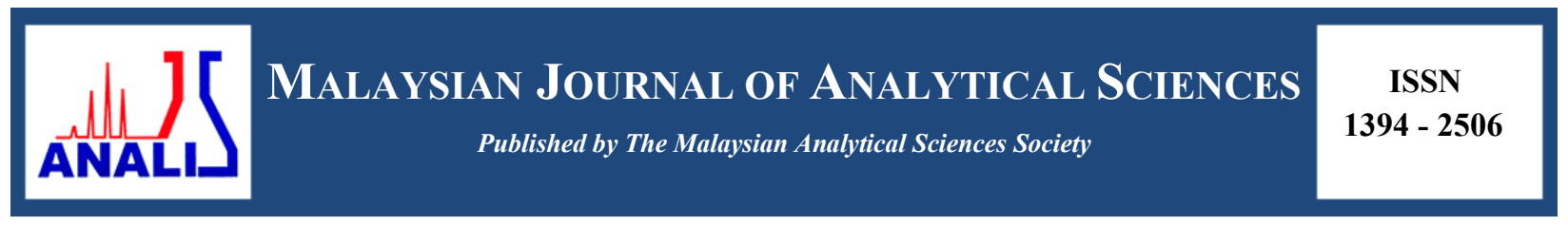

\title{
A NEW AUTOMATED GAS CHROMATOGRAPHY/SOLID PHASE MICROEXTRACTION PROCEDURE FOR DETERMINING $\alpha$-FLUORO- $\beta$-ALANINE IN URINE
}

\author{
(Kaedah Baru Pengekstrakan Mikro Fasa Pepejal/Kromatografi Gas Berautomatik \\ untuk Penentuan $\alpha$-Fluoro- $\beta$-Alanina di dalam Urin) \\ Stefano Dugheri ${ }^{1 *}$, Alessandro Bonari ${ }^{2}$, Ilenia Pompilio $^{2}$, Matteo Gentili ${ }^{3}$, Manfredi Montalti ${ }^{2}$, Nicola Mucci $^{2}$, \\ Giulio Arcangeli ${ }^{2}$ \\ ${ }^{I}$ Laboratorio di Igiene e Tossicologia Industriale, \\ Azienda Ospedaliero-Universitaria Careggi, Firenze, Italy \\ ${ }^{2}$ Dipartimento di Medicina Sperimentale e Clinica, \\ Università degli Studi di Firenze, Firenze, Italy \\ ${ }^{3}$ Giotto Biotech Srl, Sesto Fiorentino, Italy \\ *Corresponding author: stefano.dugheri@unifi.it
}

Received: 15 February 2017; Accepted: 16 June 2017

\begin{abstract}
In industrial hygiene, biomarkers maintain their promise to reveal the true extent of occupational exposure. The environmental limit values proposed by industrial hygienist associations are more than biological, health-based values indicating professional hazards to humans. High-throughput screening of samples is therefore the strategy of choice to detect occupational exposure biomarkers, yet it requires user-friendly apparatus that give relatively prompt results while ensuring high degrees of selectivity, precision, accuracy and automation, particularly in preparation processes. In light of the above, this contribution describes a novel gas chromatography/triple quadrupole mass spectrometry/positive chemical ionisation approach for determining urinary $\alpha$-fluoro- $\beta$-alanine, a metabolite of 5 -fluorouracil, the most widely employed antineoplastic drug. In this new procedure chromatography's sensitivity is combined with the user-friendliness of alkyl chloroformate/trialkyloxonium on-sample derivatizations followed by solid-phase microextraction sampling, to which is added the quantitative accuracy afforded using a specific isotope-labelled internal standard. The quantification limit for $\alpha$-fluoro- $\beta$-alanine was $25.4 \mu \mathrm{g} / \mathrm{L}$. Intra- $(3.8 \%)$ and intersession (4.5\%) repeatability was also evaluated. This method serves to identify suitable risk-control strategies for occupational hygiene conservation programs.
\end{abstract}

Keywords: $\alpha$-fluoro- $\beta$-alanine, solid phase microextraction, gas chromatography, occupational medicine

\section{Abstrak}

Dalam industri kesihatan, penanda biologi mengekalkan peranannya untuk mendedahkan sejauh mana keselamatan pekerjaan. Nilai had persekitaran yang dicadangkan oleh persatuan industri kesihatan melebihi daripada aspek biologi, iaitu tahap berasaskan kesihatan yang menunjukkan bahaya kepada manusia. Melalui saringan sampel, pemilihan strategi penting untuk mengesan pekerjaan yang terdedah kepada penanda biologi, maka alatan mesra pengguna yang memberikan keputusan segera disamping memastikan nilai kepilihan, kejituan, ketepatan dan bersifat automatik perlulah menjadi sebahagian proses tersebut. Sehubungan itu, sumbangan kajian ini adalah membincangkan kaedah novel kromatografi gas/spektrometri jisim caturkutub ganda tiga/pengionan kimia positif digunakan untuk penentuan $\alpha$-fluoro- $\beta$-alanina di dalam urin, iaitu metabolit 5-fluorourasil yang digunakan secara meluas sebagai dadah antineoplastik. Melalui prosedur baru ini, sensitiviti kromatografi digabungkan bersama menggunakan kloroformat/trialkiloksonium di ikuti oleh pensampelan pengekstrakan mikro fasa pepejal, di mana ketepatan kuantitatif analisis didorong oleh penggunaan larutan piawai internal berlabel isotop. Had kuantifikasi $\alpha$-fluoro- $\beta$ - 


\section{Dugheri et al: A NEW AUTOMATED GAS CHROMATOGRAPHY/SOLID PHASE MICROEXTRACTION PROCEDURE FOR DETERMINING $\alpha$-FLUORO- $\beta$-ALANINE IN URINE}

alanina ialah $25.4 \mu \mathrm{g} / \mathrm{L}$. Kebolehulangan intra- (3.8\%) dan inter- (4.5\%) juga telah di uji. Kaedah ini menyediakan strategi kawalan penilaian risiko yang sesuai untuk program pemuliharaan kesihatan pekerjaan.

Kata kunci: $\alpha$-fluoro- $\beta$-alanina, pengekstrakan mikro fasa pepejal, kromatografi gas, pekerjaan perubatan

\section{Introduction}

5-fluorouracil has been one of the most frequently used antineoplastic drugs in the world for more than 20 years, and it is still considered to be among the most active cytostatic agents in advanced colorectal cancer as well as for malignancies of the head and neck [1]. In Italy, more than $400 \mathrm{~kg}$ are being administered each year [2]. In addition to the therapeutic effects, however, many side effects are known, such as leukopenia, stomatitis, diarrhea, nausea, thrombocytopenia and a decrease in erythrocyte precursors in the marrow [3,4]. Several groups of workers, such as oncology nurses involved in the preparation and administration of this antineoplastic drug, as well as personnel employed in pharmaceutical plants, are occupationally exposed to this substance. In the processes of health riskassessment at work, biological monitoring of occupational exposure often plays a central role in identifying the suitable risk-control strategies and hygiene conservation programs. The availability of a highly-sensitive, compoundselective and validated analytical method for measuring a suitable marker of occupational exposure would allow personnel to know the true extent of exposure.

Although the bio-transformation of 5-fluorouracil in humans was described 30 years ago, when a patient study found that $80 \%$ of the dose is quickly excreted in urine as $\alpha$-fluoro- $\beta$-alanine (FBAL), no governmental industrial hygienist association has ever mentioned FBAL health-based values as indicators of human professional exposure to this anticancer drug. In the field of occupational medicine, few analytical methods have been published to measure urinary FBAL, and their very low number of positive biological samples demonstrates the need to adopt more sensitive analytical methods. The existing assays have limitations, namely: their complexity, their use of solvents, and/or the need for clean-up steps to extract and eliminate interfering compounds from the urine, all of which involved lengthy manual operations, bigger costs, uncertainty in the determination analysis, and the possible loss of analyte. For these reasons, simultaneous and more sensitive assay methods than those available were needed; furthermore, many researchers have called for standardization of analytical factors affecting FBAL determination [2, 5 - 12].

Sample preparation remains one of the more time-consuming and error-prone aspects of analytical chemistry. Over the last 10 years, miniaturization has attracted much attention and has driven solvent and sample savings, sample enrichment, rapid sample preparation, and easier automation. Solid-phase microextraction (SPME) analysis is considered one of the major advances that shaped $20^{\text {th }}$ century analytical chemistry [13]. It integrates sampling, extraction, concentration and sample introduction into a single step, without any polluting, organic solvent for extraction [14-17].

Accordingly, we sought to simplify sample treatment by using the SPME technique. The efficiency of alkyl chloroformate/trialkyloxonium on-sample derivatizations has been demonstrated, as has the success of quantitative determination by gas chromatography (GC) coupled with triple quadrupole-mass spectrometry (QpQ-MS)/positive chemical ionisation (PCI). By combining these procedures, we propose a new user-friendly apparatus which provides relatively prompt results with high degrees of selectivity, precision and accuracy.

\section{Materials and Methods}

\section{On-sample propyl chloroformate-trimethyloxonium tetrafluoroborate (TMO) derivatizations}

To convert the FBAL (CAS n. 867-84-5, Cat. n. F0185, TCI Europe) into related N-propyl carbamate, $100 \mu \mathrm{L}$ of propyl chloroformate (CAS n. 109-61-5, Cat. n. 249467, Aldrich) derivatizating agent was added to a $20.0 \mathrm{~mL}$ vial containing $0.5 \mathrm{~mL}$ of urine and $10 \mu \mathrm{L}$ of 2,3,3-D3 (R, S)-3-amino-2-fluoropropanoic acid (FBAL-D3) internal standard (IS) water solution $(5 \mu \mathrm{g} / \mathrm{mL})$ and continuously agitated for 30 minutes with a magnetic stirring bar. To convert the FBAL carboxyl group, derivatization with TMO (CAS n. 420-37-1, Cat. n. 281077, Aldrich) was performed in two steps at room temperature with agitation, after previous dilution with $1.5 \mathrm{~mL}$ of water. About 20 mg of sodium carbonate $\left(\mathrm{Na}_{2} \mathrm{CO}_{3}\right)$ were added and within 4 minutes approximately $30 \mathrm{mg}$ of solid TMO were added in two aliquots. After 1 minute, the solution was neutralized with about $15 \mathrm{mg}$ of sodium bicarbonate $\left(\mathrm{NaHCO}_{3}\right)$. 
This procedure was repeated. Finally, sodium chloride $(0.5 \mathrm{~g})$ was added for salting out and the vials were processed for on-line or off-line extraction.

\section{On-line headspace (HS-SPME) and xyz robotic apparatus}

Automation of the GC procedure was achieved using a new Flex autosampler (EST Analytical, Fairfield, USA). For HS-SPME absorption, samples were incubated at $60^{\circ} \mathrm{C}$ with a pulsed agitation (on for $2 \mathrm{~s}$ at $500 \mathrm{rpm}$ and off for 4 s), before the polyacrylate (PA) $85 \mu \mathrm{m}$ SPME fiber (Cat. n. 57305, Supelco) was inserted into the vial, under the same temperature/agitation conditions. After absorption, the SPME fiber was introduced into the GC injector port by $x y z$ autosampler.

\section{Off-line HS-SPME sampling and $x y z$ robotic apparatus}

The SPME Multi Off-Line Sampler (Chromline, Prato, Italy) is a holder designed to be used with FFA SPME fibers; in our case PA $85 \mu \mathrm{m}$ SPME FFA (Cat. n. FFA 57294-U, Supelco) were used. The holder acts as a support when exposing the SPME fiber in the vial, after which it is placed on the plate of the 15-position magnetic stirrer (Chromline) at $60{ }^{\circ} \mathrm{C}$. After exposure, the FFA is removed from the Multi Off-Line Sampler and placed into the 45-position Multi Fiber eXchange (MFX, Chromline, Prato, Italy), which performs automated exchanges of the fibers. For desorption the fiber is put into a Flex $x y z$ autosampler (EST Analytical) with GC instrumentation equipped with Merlin Microseals (Cat. n. 24817-U, Sigma-Aldrich). A connection with the Laboratory Information Management System (Bika Lab System) provides a user-programmable suite of options.

\section{GC/QpQ-MS}

Analyses were performed with a Varian 3900 GC equipped with electronic flow control and a Varian 320-QpQ-MS (Varian Inc.) detector. A MEGA-5-MS fused silica capillary column (internal diameter $0.25 \mathrm{~mm}$, length $30 \mathrm{~m}$ and film thickness $0.25 \mu \mathrm{m}$, Cat. No. MS-5-025-025-30, MEGA, Legnano, Italy) was used. For desorbing the analytes, the SPME fiber was introduced into the 1177 Varian GC injector port.

\section{Synthesis of FBAL-D3}

FBAL-D3 was synthesized following the protocol reported by Gani et al. [18] with slight modifications. First, DLSerine D3 $(850 \mathrm{mg}, 8 \mathrm{mmol})$ was suspended in dry methanol $(16 \mathrm{~mL})$ in a nitrogen $\left(\mathrm{N}_{2}\right)$ atmosphere. After cooling down the suspension with an ice bath, thionyl chloride $(1.635 \mathrm{~mL}, 12.5 \mathrm{mmol})$ was added slowly. The mixture was stirred for 10 minutes then warmed to room temperature (r.t.) and stirred for 1 hour. Evaporation of the solvent afforded an oily residue. Secondly, DL-Serine D3 methyl ester $(980 \mathrm{mg}, 8 \mathrm{mmol})$, benzyl bromide (2 mL, 16.8 $\mathrm{mmol}), \mathrm{NaHCO}_{3}(3.336 \mathrm{~g}, 40 \mathrm{mmol})$, dry tetrahydrofuran (THF) $(10 \mathrm{~mL})$ and dry dimethyl sulfoxide $(3.2 \mathrm{~mL})$ were placed in a flask in an $\mathrm{N}_{2}$ atmosphere and heated to $80{ }^{\circ} \mathrm{C}$. After 5 hours, the reaction was completed. The mixture was diluted with ethyl acetate (EtOAc) and washed with water three times, dried over sodium sulfate and concentrated. The residue was purified by flash column chromatography on silica gel (hexane/EtOAc 5:1, then 4:1), resulting in $1.44 \mathrm{~g}$ of pure product. Third, a solution of DL-serine D3 $N, N$-dibenzylamino methyl ester $(1.20 \mathrm{~g}, 4.0$ $\mathrm{mmol})$ in dry THF $(20 \mathrm{~mL})$ was added slowly to a solution of diethylaminosulfur trifluoride $(0.6 \mathrm{~mL}, 4.8 \mathrm{mmol})$ in dry THF $(20 \mathrm{~mL})$ at r.t in an $\mathrm{N}_{2}$ atmosphere and stirred for 30 minutes.

Ice and EtOAc were added to the solution followed by solid $\mathrm{NaHCO}_{3}$ until effervescence ceased. The aqueous phase was extracted with EtOAc. The organic phases were combined, washed with water three times and dried on $\mathrm{Na}_{2} \mathrm{SO}_{4}$. The solvent was removed under reduced pressure (r.p.). Fourth, DL- $\alpha$-Fluoro- $\beta-N, N$-dibenzyl alanine D3 methyl ester $(970 \mathrm{mg}, 3.2 \mathrm{mmol})$ was dissolved in absolute ethanol $(50 \mathrm{~mL})$ and $1 \mathrm{M} \mathrm{HCl}(1 \mathrm{eq})$; to this solution $10 \% \mathrm{Pd} / \mathrm{C}$ $(100 \mathrm{mg}$ ) was added. The mixture was stirred in a hydrogen atmosphere for two days, then filtered on Celite and washed with ethanol. The alcohols were concentrated under r.p. and treated with $6 \mathrm{M} \mathrm{HCl}$ for $90 \mathrm{~min}$. The solvent was removed under r.p. and the residue dissolved in water and applied to a column of Amberlite IR45 (OH) using water as eluent. After $100 \mathrm{~mL}$ of eluent, the solution was concentrated under r.p. and precipitated from water/acetone, obtaining pure FBAL-D3 as a white solid (236 mg, 50\% yield).

\section{Method validation}

Calibration samples were prepared and analyzed to obtain a calibration curve. Six calibration samples were obtained $(30,60,120,240,480,960 \mu \mathrm{g} / \mathrm{L})$ and six analyses for each of the calibration samples were performed. Least-square 


\section{Dugheri et al: A NEW AUTOMATED GAS CHROMATOGRAPHY/SOLID PHASE MICROEXTRACTION PROCEDURE FOR DETERMINING $\alpha$-FLUORO- $\beta$-ALANINE IN URINE}

linear regression (LSLR) analysis was used to estimate slopes (m) and intercepts (b) of calibration lines $y=m x+b$, where $\mathrm{y}$ is the ratio between the chromatographic area of the analyte and the relative IS, and $\mathrm{x}$ the concentration of FBAL ( $\mu \mathrm{g} / \mathrm{L}$ of urine). The limit of detection (LOD) of the assay was calculated according to the following equation 1:

$$
\mathrm{LOD}=\left(3 \mathrm{SE}_{\mathrm{b}}+\mathrm{b}\right) / \mathrm{m}
$$

where $\mathrm{SE}_{\mathrm{b}}$ is the internal standard error of the intercept [19]. The precision of the assay (as a coefficient of variation, $\mathrm{CV} \%$ ) was based on both within-session and inter-session repeatability. Accuracy was evaluated by the recoveries (calculated from the percentage ratio between the measured and the nominal concentration solutions) at all concentrations used for the calibration plot. Values of accuracy were then compared with the requirements of the US Food and Drug Administration for analytical method validation.

\section{Results and Discussion}

In previous studies, the oft-reported use of solvents and/or clean-up steps were necessary to extract and eliminate most of the interfering compounds from the urine. These procedures resulted in many manual operations, uncertainty of the determination, higher overall costs of the method, and possible analyte loss. Accordingly, we developed a method where the HS-SPME technique was applied after on-sample derivatization, and then coupled with quantitative determination via GC/QpQ-MS. Four fundamental aspects motivated this choice.

\section{HS-SPME}

The first objective was to develop derivatization conditions on HS-SPME technologies to obtain compounds which are not only stable under a variety of conditions, but also easily amenable to sampling, to GC separation, and to MS identification. Since FBAL determination in urine by this technique for previous alkylchloroformate/ trialkyloxonium derivatizations had not been previously reported, the equilibrium and kinetics of the reaction product, with regards to SPME, had to be both theoretically explored and experimentally proven. In a previous work [20], the HS-SPME technique had been used in a three-phase process in which a liquid polymeric coating, a headspace and an aqueous solution were involved. The mass (n) of analytes absorbed by the coating after the equilibrium has been reached is related to the overall equilibrium of analytes in the three-phase system as follows in equation 2:

$$
\mathrm{N}=\left(\mathrm{C}_{0} \mathrm{~V}_{1} \mathrm{~V}_{2} \mathrm{~K}_{1} \mathrm{~K}_{2}\right) /\left(\mathrm{K}_{1} \mathrm{~K}_{2} \mathrm{~V}_{1}+\mathrm{K}_{2} \mathrm{~V}_{3}+\mathrm{V}_{2}\right)
$$

where $\mathrm{K}_{1}$ is the SPME coating/HS partition coefficient, $\mathrm{K}_{2}$ is the HS/aqueous matrix partition coefficient, $\mathrm{C}_{0}$ is the initial concentration of the analyte in the aqueous solution, and $V_{1}, V_{2}$ and $V_{3}$ are the volumes of the coating, the aqueous solution, and the HS, respectively. Since the $\mathrm{K}$ values of the analytes (where $\mathrm{K}=\mathrm{K}_{1} \times \mathrm{K}_{2}$ ) are often very close to the octanol-water partition coefficient $\left(\mathrm{K}_{\text {ow }}\right)$, and $\mathrm{K}_{2}=\mathrm{K}_{\mathrm{H}} / \mathrm{RT}$, where $\mathrm{K}_{\mathrm{H}}$ is Henry's constant $\left(\mathrm{C}_{0}\right.$, concentration gas phase $/ \mathrm{C}_{0}$, concentration liquid phase). It follows that the equilibrium is controlled by $\mathrm{K}_{\mathrm{ow}}$ and $\mathrm{K}_{\mathrm{H}}$ values. The values $\mathrm{K}_{\mathrm{ow}}$ and $\mathrm{K}_{\mathrm{H}}$ can be found in the literature or calculated, and in this way, it is possible to know in advance whether the HS-SPME method offers some advantages or vice versa. Moreover, the constant of distribution estimated from physicochemical tables or by using the structural unit contribution method can anticipate trends in SPME analysis.

For example, Performs Automated Reasoning in Chemistry (ARChem, Danielsville, Georgia, USA) is a physicochemical calculator that uses computational algorithms based on the fundamental chemical structures to foresee a wide variety of reactivity parameters strictly based on molecular structure. The $\mathrm{K}_{\mathrm{H}}$ of the N-propyl carbamate/methyl ester FBAL-derivate was $0.13 \mathrm{~atm} \mathrm{~cm}^{3} / \mathrm{mol}$ (Table 1), which agreed with that reported by Pacenti et al. [21]; this confirmed that HS-SPME is efficient under such conditions. 
Table 1. Physical properties and partition coefficients of N-propyl carbamate/methyl ester FBAL-derivates evaluated using SPARC software

\begin{tabular}{lcccccc}
\hline SMILES strings & $\begin{array}{c}\mathbf{T}_{\text {eb }} \\
\left({ }^{\circ} \mathbf{C}\right)\end{array}$ & $\begin{array}{c}\mathbf{D}_{\text {water }} \\
\left(\mathbf{c m}^{2} / \mathbf{s}\right)\end{array}$ & $\begin{array}{c}\mathbf{D}_{\text {air }} \\
\left(\mathbf{c m}^{2} / \mathbf{s}\right)\end{array}$ & $\begin{array}{c}\mathbf{K}_{\mathbf{H}} \\
\left(\mathbf{a t m ~ \mathbf { m } ^ { 3 }} / \mathbf{m o l}\right)\end{array}$ & $\begin{array}{c}\mathbf{K}_{\text {ow }} \\
(\mathbf{L o g})\end{array}$ & $\begin{array}{c}\mathbf{P}_{\text {vap }} \\
(\mathbf{l o g}(\mathbf{a t m}))\end{array}$ \\
\hline $\mathrm{O}=\mathrm{C}(\mathrm{NCC}(\mathrm{F}) \mathrm{C}(=\mathrm{O}) \mathrm{OC}) \mathrm{OCCC}$ & 271.8 & $6.52 * 10^{-6}$ & 0.0483 & $1.25 * 10^{-7}$ & 1.31 & -5.3 \\
\hline
\end{tabular}

\section{Alkyl chloroformate derivatization conditions}

Chloroformates have been widely used to convert amines into carbamates in aqueous media. One-step treatment of amino acids with chloroformates and alcohols of the same alkyl with catalysis by pyridine met the basic criteria required for an ideal procedure: very simple sample handling in aqueous solutions and derivatization completed within a few seconds with microliter amounts of reagent of negligible cost [22 - 25]. Modification in the reaction conditions towards using reagents with different alkyls appeared to be useful $[26,27]$ in enabling researchers to prepare a wide variety of esters tailored to the analytical needs of specific tasks. In our method, we decided to carry out such derivatization in water, without using any alcoholic solvent, in order to avoid the formation of undesired side products as those described by Wang et al. [28].

A novel approach to the derivatization of carboxylic groups by the use of TMO, a methyl group of oxonium ions reacts with the anion of the carboxylic group to form methyl ester. This method employs a sample derivatization technique to convert polar substances into hydrophobic compounds, whose volatility is sufficiently high for HS$\mathrm{SPME} / \mathrm{GC}$ determination. Trialkyloxonium ions (Meerwein salts), $\mathrm{R}_{3} \mathrm{O}^{+}$, with various counterions such as $\mathrm{SbF}_{6}^{-}$, $\mathrm{BF}_{4}^{-}, \mathrm{SbCl}_{6}^{-}$and $\mathrm{PF}_{6}^{-}$, are excellent alkylating agents for nucleophiles containing such heteroatoms as $\mathrm{N}, \mathrm{O}$, or $\mathrm{S}$ [17, 21, $29-31]$. The application of TMO as a methylating agent together with propyl chloroformates as agent without catalysis by pyridine was implemented in this work. The reaction, occurring under mild conditions at room temperature, is completed in a few minutes (Figure 1).

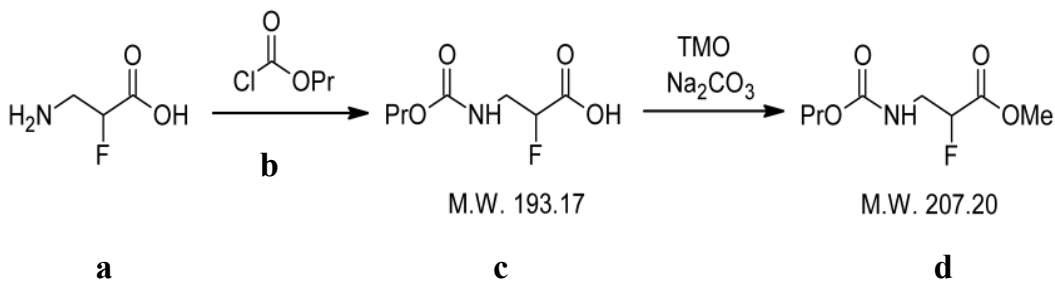

Figure 1. (a) FBAL and (b) propyl chloroformate reaction to related (c) alkyl chloroformate and subsequent trialkyloxonium derivatization which forms (d) FBAL-N-propyl carbamate-methylester

\section{${ }^{1}$ H-NMR analysis of propyl chloroformate/TMO derivatization}

The reaction of FBAL and propyl chloroformate was investigated by NMR spectroscopy in D2O, in order to ensure the conversion of the amino group into the corresponding propyl carbamate. The sample was placed in a clear tube and analyzed by a Varian Gemini NMR instrument at $200 \mathrm{MHz}$. Following the addition of sub stoichiometric quantities of propyl chloroformate, a new set of signals appeared immediately, as the intensity of the reagent's signals decreased, until completely disappearing when a stoichiometric amount of the chloroformate was added. This confirms that FBAL spontaneously reacts with propyl chloroformate in aqueous phase in a quantitative yield. After alkalization of the same solution with $\mathrm{Na}_{2} \mathrm{CO}_{3}$, TMO was added stepwise till a stoichiometric amount was reached. NMR spectra showed an increasing signal of methyl ester until the reagent was completely converted.

\section{Choice of GC/QpQ-MS/Positive Chemical Ionization (PCI)}

In this work, PCI was used for the analysis of FBAL-derivates to increase the signal intensity of the molecular ions, and then coupled with QpQ-MS during Selected Reaction Monitoring (SRM) to increase their selectivity compared to the background matrix. For PCI we selected methane as the reactive gas, which produced a few fragments of FBAL, as the parent ion was $\mathrm{m} / \mathrm{z} 208(\mathrm{M}+\mathrm{H})^{+}$as peak to be used as precursor ion in QpQ-MS (Figure 2). 

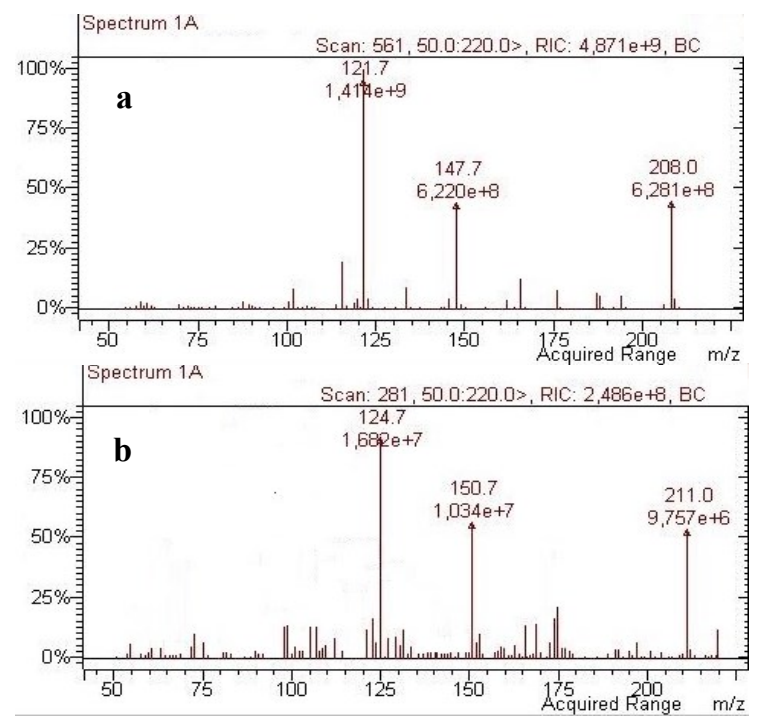

Figure 2. GC/SCAN-MS/PCI spectrum of FBAL (a) and FBAL-D3 (b)

The GC and QpQ-MS/PCI parameters are displayed in Table 2. As indicated in Table 3, the resulting calibration curves for FBAL were linear in the investigated range, showing a correlation coefficient $>0.99$.

Table 2. GC and QpQ-MS/PCI parameters

\begin{tabular}{ll}
\hline GC conditions & \\
\hline $\begin{array}{l}\text { Injection } \\
\text { Oven }\end{array}$ & $\begin{array}{l}30{ }^{\circ} \mathrm{C}, 2: 1 \mathrm{split} \text { mode. Liner } 0.75 \mathrm{~mm} \text { i.d. } \\
50{ }^{\circ} \mathrm{C}(1 \mathrm{~min}) \text { increased at } 10{ }^{\circ} \mathrm{C} / \mathrm{min} \text { to } 180{ }^{\circ} \mathrm{C} \text { and } 30{ }^{\circ} \mathrm{C} / \mathrm{min} \text { to } 300^{\circ} \mathrm{C}(2 \mathrm{~min}) . \\
\text { (Run time } 20.00 \mathrm{~min})\end{array}$ \\
$\begin{array}{l}\text { Column flow } \\
\text { Retention times }\end{array}$ & Helium $(99.999 \%)$ at a flow rate of $1.2 \mathrm{~mL} / \mathrm{min}$ \\
GC interface & $280{ }^{\circ} \mathrm{C}$ \\
\hline MS parameters & \\
\hline Mode & Positive CI \\
Filament & Electron energy, 70 eV. Filament current, $50 \mu \mathrm{A}$ \\
Source & Temperature, 200 ${ }^{\circ} \mathrm{C}$. Pressure, 8 Torr \\
CI reagent & Methane \\
Collision gas & CID gas, Argon. CID gas pressure, 2.00 mTorr \\
Collision energy & FBAL, 5 eV. FBAL-D3, 10 eV \\
\hline SRM transition & \\
\hline FBAL-derivate & Fragments Q1 $>\mathrm{Q} 3(208>148$, quantification) \\
FBAL-D3-derivate & Fragments Q1 $>\mathrm{Q} 3(211>125$, quantification) \\
\hline
\end{tabular}


Table 3. Calibration curve, accuracy and precision (coefficient of variation) of the FBAL analytical method

\begin{tabular}{ll}
\hline $\begin{array}{l}\text { FBAL } \\
\text { (Nominal Concentration, } \boldsymbol{\mu g} / \mathbf{L} \text { ) }\end{array}$ & $\begin{array}{l}\text { FBAL } \\
\text { (Measured Concentration, } \boldsymbol{\mu g} / \mathbf{L} \text { ) }\end{array}$ \\
\hline 30 & 21.0 \\
60 & 46.6 \\
120 & 109.8 \\
240 & 230.4 \\
480 & 463.1 \\
960 & 937.4 \\
LSLR parameters & $\mathrm{m}=0.0287, \mathrm{~b}=0.2403$ \\
Coefficient of Correlation & 0.992 \\
Standard Error & 0.054 \\
LOD ( $\mu$ g/L) & 7.7 \\
LOQ ( $\mu$ g/L) & 25.4 \\
Within-session accuracy $(\%)$ & 4.3 \\
Within-session repeatability $(\%)$ & 3.8 \\
Inter-session repeatability $(\%)$ & 4.5 \\
\hline
\end{tabular}

Accuracy was within $15 \%$ of the theoretical concentration, in line with the requirement of the US Food and Drug Administration. The new SPME Multi Off-Line Sampler proposed in this study integrates the MFX (Figure 3).

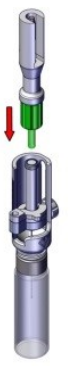

Figure 3. SPME Multi Off-Line Sampler holder

Several preparation steps immediately before sample injection have been automated, allowing just-in-time sample preparation. Below is an example of the advantages of using an SPME FFA Multi Off-Line Sampler: calculate an extraction time of 40 minutes for FBAL-derivate equilibrium in a three-phase SPME system plus an analysis time of 20 minutes (Figure 4). 


\section{Dugheri et al: A NEW AUTOMATED GAS CHROMATOGRAPHY/SOLID PHASE MICROEXTRACTION PROCEDURE FOR DETERMINING $\alpha$-FLUORO- $\beta$-ALANINE IN URINE}

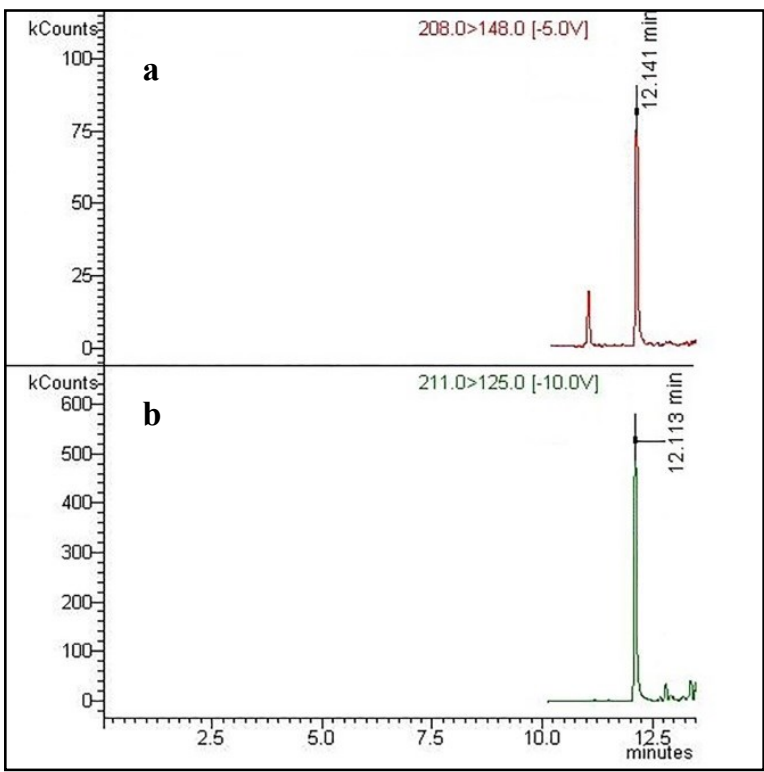

Figure 4. GC chromatograms of FBAL- (a) and FBAL-D3- (b) derivate

The results are excellent, with a reduction in total analysis time of 725 minutes (30 samples processed), compared to conventional SPME on-line analysis (Figure 5).

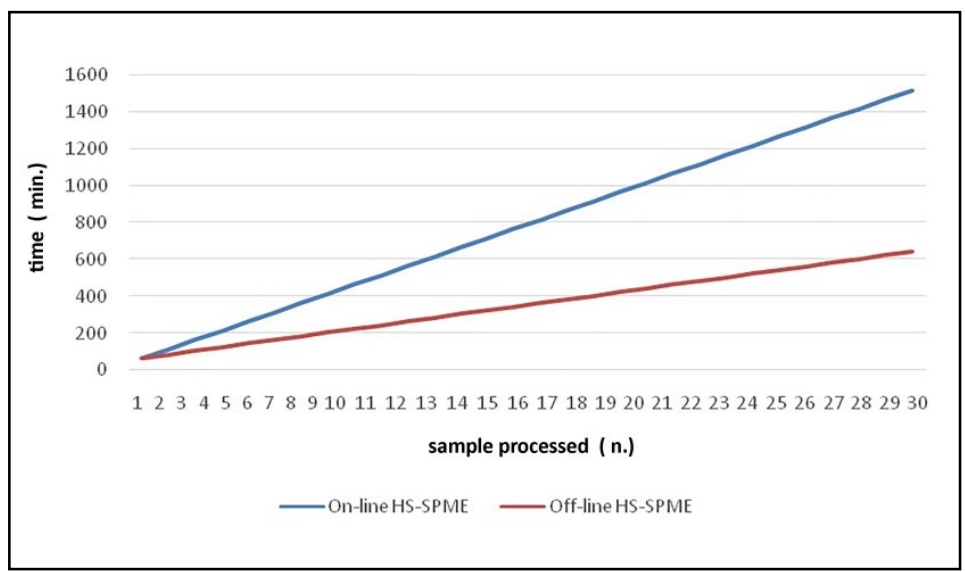

Figure 5. Off-Line vs. On-Line SPME extraction

\section{Conclusion}

Our data suggests that automated SPME extraction coupled with GC/QpQ-MS/PCI is a viable alternative for FBAL analyses. Customized, automatized MS apparatus for high-throughput screening are not only user-friendly, but they reduce the costs of monitoring occupational health hazards. New sample preparation techniques are currently being increasingly explored because of the considerable need for information management, the automation of sample preparation, and the integration of data management into the analytical process. Lastly, we expanded the application of this methodology by carrying out analyses of other amino acids. 


\section{Acknowledgements}

We thank the Azienda Ospedaliero-Universitaria Careggi (Florence, Italy), one of the largest polyclinics in Italy, for allowing us access to the wards and their employees, and particularly Fabrizio Niccolini, Daniela Tognoni and Anna Maria Tognoni, for enduring our presence and participating in the study. Furthermore, the authors gratefully acknowledge Marco Colpo for statistical analysis support.

\section{References}

1. Breda, M. and Barattè, S. (2010). A review of analytical methods for the determination of 5-fluorouracil in biological matrices. Analytical Bioanalytical Chemistry, 397(3): 1191 - 1201.

2. Rubino, F. M., Verduci, C., Buratti, M., Fustinoni, S., Campo, L., Omodeo-Salè, E., Giglio, M., Iavicoli, S., Brambilla, G. and Colombi, A. (2006). Assay of urinary alpha-fluoro-beta-alanine by gas chromatography-mass spectrometry for the biological monitoring of occupational exposure to 5-fluorouracil in oncology nurses and pharmacy technicians. Biomedical Chromatography, 20(3): $257-266$.

3. Nair, K. L., Jagadeeshan, S., Nair, S. A. and Kumar, G. S. (2011). Biological evaluation of 5-fluorouracil nanoparticles for cancer chemotherapy and its dependence on the carrier, PLGA. International Journal of Nanomedicine, 6:1685 - 1697.

4. Jaferian, S., Negahdari, B. and Eatemadi, A. (2016). Colon cancer targeting using conjugates biomaterial 5flurouracil. Biomedicine \& Pharmacotherapy, 84: 780 - 788.

5. Sessink, P. J., Timmersmans, J. L., Anzion, R. B. and Bos, R. P. (1994). Assessment of occupational exposure of pharmaceutical plant workers to 5-fluorouracil. Journal Occupational Medicine, 36(1):79-83.

6. Anderson, D., Kerr, D. J., Blesing, C., and Seymour, L. W. (1997). Simultaneous gas chromatographic-mass spectrophotometric determination of alpha-fluoro-beta-alanine and 5-fluorouracil in plasma. Journal of Chromatography B: Biomedical Sciences and Applications, 688(1): 87 - 93.

7. Licea-Perez, H., Wang, S. and Bowen, C. (2009). Development of a sensitive and selective LC-MS/MS method for the determination of alpha-fluoro-beta-alanine, 5-fluorouracil and capecitabine in human plasma. Journal of Chromatography. B, Analytical Technologies in the Biomedical and Life Sciences, 877(11-12): 1040 - 1046.

8. Ndaw, S., Denis, F., Marsan, P., d'Almeida, A. and Robert, A. (2010). Biological monitoring of occupational exposure to 5 -fluorouracil: urinary $\alpha$-fluoro- $\beta$-alanine assay by high performance liquid chromatography tandem mass spectrometry in health care personnel. Journal of Chromatography. B, Analytical Technologies in the Biomedical and Life Sciences, 878(27): 2630 - 2634.

9. Bos, R. P., Weissenberger, B. F. J. and Anzion, R. B. M. (1998). $\alpha$-Fluoro- $\beta$-alanine in urine of workers occupationally exposed to 5-fluorouracil in a 5-fluorouracil producing factory. Biomarkers, 3(1): $81-87$.

10. Furuhata, T., Kawakami, M., Okita, K., Kimura, Y., Kihara, C., Tsuruma, T., Ohmura, T., Yamaguchi, K., Hata, F., Katsuramaki, T., Sasaki, K. and Hirata, K. (2006). Plasma level of a 5 -fluorouracil metabolite, $\alpha$-fluoro- $\beta$ alanine correlates with dihydropyrimidine dehydrogenase activity of peripheral blood mononuclear cells in 5fluorouracil treated patients. Journal of Experimental and Clinical Cancer Research, 25(1): 79 - 82.

11. Yoshida, J., Koda, S., Nishida, S., Nakano, H., Tei, G. and Kumagai, S. (2013). Association between occupational exposure and control measures for antineoplastic drugs in a pharmacy of a hospital. Annals of Occupational Hygiene, 57(2): 251 - 260.

12. Poupeau, C., Tanguay, C., Plante, C., Gagné, S., Caron, N. and Bussières, J. F. (2016). Pilot study of biological monitoring of four antineoplastic drugs among Canadian healthcare workers. Journal of Oncology Pharmacy Practice, April:1-10.

13. Handley, J. and Harris, C. M. (2001). Great ideas of a decade. Analytical Chemistry, 73(23): 660 - 666.

14. Bianchi, F., Bisceglie, F., Dugheri, S., Arcangeli, G., Cupelli, V., Del Borrello, E., Sidisky, L. and Careri, M. (2014). Ionic liquid-based solid phase microextraction necklaces for the environmental monitoring of ketamine. Journal of Chromatography A, 1331: $1-9$.

15. Sassolini, A., Dominici, C., Saurini, M. T., Guidotti, M., Cenciarelli, O., Malizia, A., Ludovici, G. M., Gabbarini, V., Gabriele, J., Bellecci, C., Palombi, L. and Gaudio, P. (2015). Development of a SPME-GC-MS based methods for analysis of organochlorinated smoke agents in soil and its applications in a former military site samples. Malaysian Journal of Analytical Sciences, 19(6): 1179 - 1186.

16. Kremser A., Jochmann, M. A., and Schmidt, T. C. (2016). SPME Arrow-evaluation of a novel solid-phase microextraction device for freely dissolved PAHs in water. Analytical and Bioanalytical Chemistry, 408(3): 943 $-952$. 
17. Dugheri, S., Bonari, A., Pompilio, I., Mucci, N., Montalti, M. and Arcangeli, G. (2016). Development of new gas chromatography/mass spectrometry procedure for the determination of hexahydrophthalic anhydride in unsaturated polyester resins. RASĀYAN Journal of Chemistry, 9(4): $657-666$.

18. Gani, D., Hitchcock, P. B. and Young, D. W. (1985). Stereochemistry of catabolism of the DNA base thymine and of the anti-cancer drug 5-fluorouracil. Journal of the Chemical Society, Perkin Transactions, 1: 1363 1372.

19. Miller, J. C. and Miller, J. N. (1984). Statistics for analytical chemistry, Ellis Horwood: Chinchester, 4: pp. 96.

20. Zhang, Z. and Pawliszyn, J. (1993). Headspace solid-phase microextraction. Analytical Chemistry, 65(14): 1843 -1852 .

21. Pacenti, M., Dugheri, S., Villanelli, F., Bartolucci, G., Calamai, L., Boccalon, P., Arcangeli, G., Vecchione, F., Alessi, P., Kikic, I. and Cupelli V. (2008). Determination of organic acids in urine by solid-phase microextraction and gas chromatography-ion trap tandem mass spectrometry previous 'in sample' derivatization with trimethyloxonium tetrafluoroborate. Biomedical Chromatography, 22(10): 1155 - 1163.

22. Hušek, P. (1998). Chloroformates in gas chromatography as general purpose derivatizing agents. Journal of Chromatography B: Biomedical Sciences and Applications, 717(1-2): 57 - 91.

23. Hušek, P., Švagera, Z., Hanzlíková, D., Řimnáčová, L., Zahradníčková, H., Opekarová, I. and Šimek, P. (2016). Profiling of urinary amino-carboxylic metabolites by in-situ heptafluorobutyl chloroformate mediated sample preparation and gas chromatography-mass spectrometry. Journal of Chromatography A, 1443: $211-232$.

24. Bianchi, F., Dugheri, S., Musci, M., Bonacchi, A., Salvatori, E., Arcangeli, G., Cupelli,V., Lanciotti, M., Masieri, L., Serni, S., Carini, M., Careri, M. and Mangia, A. (2011). Fully automated solid-phase microextraction-fast gas chromatography-mass spectrometry method using a new ionic liquid column for highthroughput analysis of sarcosine and N-ethylglycine in human urine and urinary sediments. Analytica Chimica Acta, 707(1-2): $197-203$.

25. Naccarato, A., Gionfriddo, E., Sindona, G. and Tagarelli, A. (2014). Development of a simple and rapid solid phase microextraction-gas chromatography-triple quadrupole mass spectrometry method for the analysis of dopamine, serotonin and norepinephrine in human urine. Analytica Chimica Acta, 810: 17 -24.

26. Makita, M., Yamamoto, S. and Kõno, M. (1976). Gas-liquid chromatographic analysis of protein amino acids as $\mathrm{N}$-isobutyloxycarbonylamino acid methyl esters. Journal of Chromatography, 120(1): 129-140.

27. Makita, M., Yamamoto, S., Sakai, K. and Shiraishi, M. (1976). Gas-liquid chromatography of the Nisobutyloxycarbonyl methyl esters of non-protein amino acids. Journal of Chromatography, 124: 92 -96.

28. Wang, J., Huang, Z. H., Gage, D. A. and Watson, J. T. (1994). Analysis of amino acids by gas chromatographyflame ionization detection and gas chromatography-mass spectrometry: simultaneous derivatization of functional groups by an aqueous-phase chloroformate-mediated reaction. Journal of Chromatography A, 663(1): $71-78$.

29. Meerwein, H., Hinz, G., Hofmann, P., Kroning, E. and Pfeil, E. (1937). Über Tertiäre Oxoniumsalze, I. Journal für praktische Chemie, 147(10-12): $257-285$.

30. Liebich, H. M. and Gesele, E. (1999). Profiling of organic acids by capillary gas chromatography-mass spectrometry after direct methylation in urine using trimethyloxonium tetrafluoroborate. Journal of Chromatography A, 843(1-2): 237 - 245.

31. Amazzini, S., Onor, M., Pagliano, E., Mester, Z., Campanella, B., Pitzalis, E., Bramanti, E. and D’Ulivo, A. (2015). Determination of thiocyanate in saliva by headspace gas chromatography-mass spectrometry, following a single-step aqueous derivatization with triethyloxonium tetrafluoroborate. Journal of Chromatography A, 1400: $124-130$. 